\title{
THE IMPACT OF WORD OF MOUTH AND DISCOUNTS ON VISIT INTENTION WITH DESTINATION IMAGE AS INTERVENING ON TOURIST DESTINATIONS IN THE CITY OF BATAM
}

\author{
Rizni Aulia Qadri \\ Universitas Internasional Batam, Batam, Indonesia \\ Corresponding author: rizniaulia37@uib.edu
}

\begin{abstract}
The Covid-19 pandemic has significantly impacted sectors in all corners of the world, especially in Indonesia. Since the lockdown, the government has forced the country to lock up foreign and domestic tourists, a large-scale closure in Indonesia, resulting in a significant decline in the tourism sector. In the last few months, tourism has reopened, so marketers compete to attract visitors with exciting promotions and reviews related to the destination, including the City of Batam. This research is classified as explanatory research, namely, research that explains the relationship variables and tests the relationship between several variables by testing several hypotheses using SmartPLS version 3 software with 390 respondents using the Hair calculation method. The results of this study indicate that Destination image, Word of Mouth, and Discount has a significant positive effect on visit intention
\end{abstract}

Keywords: Visit Intention, Destination Image, Discount, WOM

\section{Introduction}

The Covid-19 pandemic in the last few years is a real phenomenon for the world, especially in Indonesia. Many countries are implementing a regional quarantine (lockdown) to suppress the spread of covid in the community, including Indonesia. Covid-19 has had a significant impact on various sectors, including Indonesian tourism, especially the city of Batam. Since covid-19, tourist visits have decreased dramatically compared to the previous year, and we can see based on the following table:

Table 1. Data on tourist visits to the City of Batam in 2018-2020

\begin{tabular}{crr}
\hline \multirow{2}{*}{ Years } & \multicolumn{3}{c}{ Tourist Visits Batam } \\
\cline { 2 - 3 } & Number Of Visits (People) & (Percent) \\
\hline 2018 & 1.887 .284 & $45.66 \%$ \\
\hline 2019 & 1.947 .943 & $47.12 \%$ \\
\hline 2020 & 298.503 & $7.22 \%$ \\
\hline Source: Central Bureau of Statistics & &
\end{tabular}

The government made a solution by reopening the tourism sector to boost the economy. So that professional marketers make competition to attract visitors to offer discounts of up to $50 \%$. With these various discounts, it is hoped that tourists will be interested in returning to travel. Discounts are one of the most effective ways to attract visitors. Many factors influence the decision to visit during this pandemic besides discounts one of them is to provide positive reviews via the internet (Abubakar et al., 2017). Tourism marketing that is carried out through the internet, such as social media, is a very advanced promotion tool at this time. The internet makes it easier for people to access tourist destinations, exchange information, and comment on each other, so we can call it word of mouth or WOM. As the range of tourism choices expand and destinations become increasingly more competitive, more destinations adopted the idea of using destination images, discounts, and the power of word of mouth to increase the value and number of visitors amid this Covid-19 pandemic. In the last few decades, there have been many studies on visit intention and destination images about tourist destinations, including (Ferns \& Walls, 2012); (Phillips et al., 2013); (Yoon et al., 2010); (Whang et al., 2016); (S. J. Lee \& Bai, 2016; Rittichainuwat \& Rattanaphinanchai, 2015) and (Nicoletta \& Servidio, 2012).

\section{Literature Review \\ Visit Intention}

To fully understand tourist visits and their future intentions in the tourism industry is essential for tourism marketers because wants and needs vary and are constantly changing with different views. Several previous studies have made an analogy for visit intentions the same as someone's purchase intention, an internal drive, and stimulus that can motivate to take any action, driven by positive encouragement and feeling about a purchasing (Kotler \& Susanto, 2001). A study (Abubakar et al., 2017) states that WOM and trust in destinations affect the desire of tourists to visit. So, based on Visit Intention, tourists to tourist 
destinations are analogous to Purchase Intention. This can be interpreted as visit activities carried out by tourists who visit tourist destinations in certain areas.

\section{Brand Image}

Studies in Europe and the United States found that destinations with a high brand image tend to have larger margins because the brand image can create consumer perceptions of buying or not buying the item (Kremer et al., 2018). From the perception of objects, what is thought, known, experienced enters a person's memory. Kotler (2005:24) that the image of a destination is the beliefs and impressions that a person has about a place. The image of a destination is not always formed from experience or facts but can be shaped to become an intense driving or driving factor for tourists to travel to a tourist destination. The destination's image based on tourist ratings may differ from one person to another. The image of a destination is an individual's perception of the characteristics of a destination that can be influenced by promotional information, mass media, and many other factors. According to (Qu et al., 2011), there are three indicators of inner destination image (Jalilvand \& Ali Heidari, 2015) as follows: 1) Cognitive destination image, consisting of the quality of experience gained by the environment. tourists and infrastructure in the environment. entertainment and cultural traditions at the destination. 2) Unique image (the image of a unique destination), consisting of the natural environment, the attractiveness of the destination, and the local attractiveness of the destination. 3) Affective destination image, which consists of pleasant, evocative, relaxing, and interesting feelings when at a destination. Research (Toudert \& Bringas-Rábago, 2016); (Putri \& Yasri, 2020), and (Albarq, 2013) stated that the image of the destination had a significant effect on visit intention. Therefore, this study shows that brand image will affect consumers' visit intention as formalized in Hypothesis 1 below:

\section{H1: Destination image has a significant positive effect on visit intention.}

\section{Word Of Mouth}

Another factor that affects the intention to visit is the Word of Mouth, both direct and internet reviews, where someone receives a positive or negative review. According to Kotler \& Keller (2009: 512). WOM is a marketing activity through an intermediary someone to someone either orally, in writing, or electronic communication tools related to the experience of purchasing services or experiences using products or services. The importance of WOM is also recognized in business to intensify promotions; in general, the dissemination of information by word of mouth is more effective, the impact can be good or bad. This WOM forms products worthy of being sold and consumed by tourists. WOM is very helpful for consumers in making purchases. Word of Mouth influences Brand Image (Majid, 2013). Word of mouth indicators, according to (Jalilvand \& Ali Heidari, 2015), include: 1) Source-recipient relationship, 2) Various channels, 3) Request for information, 4) Message retention, 5) Motivation to disclose information. Meanwhile, according to (Goyette et al., 2010) and (Qadry \& Yasri, 2019), research revealed that WOM has several dimensions, namely: 1) WOM intensity, namely the amount of information, interactions, opinions, or comments received by consumers, 2) valence WOM, namely consumer interest in a product by buying a product based on opinions and recommendations from other consumers, and 3) WOM content, namely information about quality, price, comfort, cleanliness, and service that consumers will buy.

Research by (Sheehan et al., 2019) that discounts have a positive and significant effect on a person's interest in buying or taking action. this study also strengthens the research conducted by (Semuel \& Lianto, 2017); (Majid, 2013); (Evanita \& Trinanda, 2018); (Yasri \& Engriani, 2018); (Novita \& Lubis, 2018); (W. I. Lee et al., 2017); (Li et al., 2018); and (Semuel \& Lianto, 2017). This shows that Electronic WOM significantly affects the destination's image and visit intention. Because WOM is the positive and negative opinions of potential customers, repeat customers, and customers who have purchased a product or company disseminated through the internet. Placement of the brand image in the minds of customers must be done continuously so that the brand image created remains strong and can be received positively. Therefore, this study shows that WOM affects brand Image and visit intention. The researchers formalized it into Hypothesis 2 and Hypothesis 3 as follows:

\section{H2: WOM has a significant positive effect on destination image \\ H3: WOM has a significant positive impact on visiting intentions}

\section{Discount}

Another factor that attracts tourists to visit is a discount as a promo in Kotler and Armstrong (2008:9) in (Putra et al., 2016) defines discount as a direct price reduction for purchases within a certain period. Discounts are determined according to the policies and objectives of each company. In general (Cavusoglu et al., 2020), if consumers can buy a commercial product at the lowest price, they will also increase the profit they receive from that product. This creates a substantial shopping value for the benefit of consumers. Sales promotions that reinforce consumers' perceptions of value are practices that businesses often benefit from. It is hoped that the discount will attract consumers to buy the product. Discounts affect the image of the destination and the visit intention. Discount indicators according to include 1) looking at special day discounts to find various things 2) Discounts have a positive effect on purchase intention. 3) I see discounts 
through store content (catalogs, etc.) 4) I wait for discounts to buy products 5) discounts as opportunities (Agmeka et al., 2019). A study by (Widyanto \& Widayanto, 2019); (Putra et al., 2016); (Cavusoglu et al., 2020); (Melania \& Ellyawati, 2018); (Setyaningsih \& Murwatiningsih, 2017) that discounts have a significant positive effect on the destination image because the more discounts provided by tourist destinations, the greater the satisfaction of visitors to make return visits and recommend them to others. Thus, the researcher suggests that discount influence brand image and visit intention as formalized into Hypothesis 4 and Hypothesis 5 as follow:

\section{H4: Discounts have a significant positive effect on destination image \\ H5: Discounts have a significant positive impact on visiting intentions}

\section{Research Methods}

This research is a study of the impact of WOM and discounts on visit intention with destination image as intervening on tourist destinations in the City of Batam with a sample of 390 respondents with the Hair calculation method, which was selected based on non-probability sampling techniques (purposive sampling) but to avoid an error questionnaire, the respondent is added to 400. The sample criteria in this study are tourists who intend to visit tourism objects in the city of Batam during the COVID-19 pandemic with a minimum age of 18 years old. This research can be classified as explanatory research. namely, research that explains the relationship variables and examines the relationship between several variables through testing several hypotheses using an approach with SmartPLS version 3 software

\section{Result and Discussion}

The result of SEM PLS analysis of Variant (R2) or Determination Test is to find out the influence of the independent variable on the dependent variable; the value of the coefficient of determination can be shown in the following table:

Table 2. R Square

\begin{tabular}{lcc}
\hline & R Square & R Square Adjusted \\
\hline Destination Image & 0,546 & 0,544 \\
Visit Intention & 0,380 & 0,375 \\
\hline
\end{tabular}

In this study, it can be seen that : R2 adjusted Destination Image of 0.544 means that the discount variable and WOM and explaining the visiting intention variable is $54.4 \%$, the remaining $45.6 \%$ is explained by other constructs outside those studied in this study, R2 adjusted visit intention of 0.375 means that destination image, discount,t, and WOM explain the variable of visiting intention by $37.5 \%$, the rest is explained by other constructs outside those studied in this study.

From processing data with SmartPLS version 3, the results are obtained as in the following table:

Table 3. Results of Path Coefficients

\begin{tabular}{lccc}
\hline Hypothesis & $\begin{array}{c}\text { Standard Deviation } \\
(\text { STDEV })\end{array}$ & $\begin{array}{c}\text { T Statistics } \\
(|\mathrm{O} / \mathrm{STDEV}|)\end{array}$ & P Values \\
\hline Destination_Image -> Visit Intention & 0,067 & 5,215 & 0,000 \\
Discount -> Destination_Image & 0,046 & 4,909 & 0,000 \\
Discount -> Visit Intention & 0,048 & 3,423 & 0,001 \\
WOM -> Destination_Image & 0,049 & 12,411 & 0,000 \\
WOM -> Visit Intention & 0,066 & 3,070 & 0,002 \\
\hline
\end{tabular}

Based on the table above shows that the results of hypothesis testing based on beta values and p-values of $0.05(5 \%)$ can be concluded that:

1. The destination image hypothesis test results on visiting intentions are positive and $p$-value $=0.000$. This shows that destination image has a significant positive effect on visiting preferences. This means that the better the destination image, the higher the intention to visit. In other words, destination image influences visiting purposes in this study, so the hypothesis is accepted.

2. The results of the discount hypothesis test on the destination image are positive and $p$-value $=0.000$. This shows that the discount has a significant positive effect on the destination image. This means that the higher the discount, the better the destination image. In other words, in this study, the discount affects the destination image to accept the hypothesis.

3. The results of the discount hypothesis test on the intention to visit are positive and $p$-value $=0.001$. This shows that the discount has a significant positive effect on visiting intentions. This means that the higher the discount is given, the greater the intention to visit. In other words, in this study, the discount influences the intention to visit. so that the hypothesis is accepted

4. The results of the WOM Hypothesis Test on the destination image are positive and $\mathrm{p}$-value $=0.000$. This shows that WOM has a significant positive effect on destination image. This means that the higher the 
WOM gave, the better the destination image. In other words, in this study, WOM influences the destination image to accept the hypothesis.

5. The results of the WOM Hypothesis Test on the intention to visit are positive and $p$-value $=0.002$. This shows that WOM has a significant positive effect on visiting preferences. This means that the higher the WOM gave, the greater the intention to visit. In other words, in this study WOM influences visiting intentions. so that the hypothesis is accepted.

\section{Conclusion}

In this study, empirical evidence found that City of Batam tourist destinations during the Covid-19 pandemic showed that word of mouth and discounts had a significant positive effect on visiting intentions with destination image as an intervening. Some solutions to this research problem can be solved by increasing most of the significance starting from the destination image on physical evidence, discounts, and also word of mouth both directly and reviews on social media like Instagram, TikTok, and Facebook.

\section{References}

Abubakar, A. M., Ilkan, M., Meshall Al-Tal, R., \& Eluwole, K. K. (2017). eWOM, revisit intention, destination trust, and gender. Journal of Hospitality and Tourism Management, 31, 220-227. https://doi.org/10.1016/j.jhtm.2016.12.005

Agmeka, F., Wathoni, R. N., \& Santoso, A. S. (2019). The influence of discount framing towards brand reputation and brand image on purchase intention and actual behavior in e-commerce. Procedia Computer Science, 161, 851-858. https://doi.org/10.1016/j.procs.2019.11.192

Albarq, A. N. (2013). Measuring the Impacts of Online Word-of-Mouth on Tourists' Attitude and Intentions to Visit Jordan: An Empirical Study. International Business Research, 7(1), 14-22. https://doi.org/10.5539/ibr.v7n1p14

Cavusoglu, S., Demirag, B., \& Durmaz, Y. (2020). Investigation of the effect of hedonic shopping value on discounted product purchasing. Review of International Business and Strategy, 31(3), 317-338. https://doi.org/10.1108/RIBS-04-2020-0034

Evanita, S., \& Trinanda, O. (2018). Marketing to $1 \mathrm{Z}$ Generations: An Analysis of West Sumaterars Youth Decision Factors When Buying Modern Snacks Minangkabau Traditional Snacks. 57(Piceeba), $146-152$. https://doi.org/10.2991/piceeba-18.2018.42

Ferns, B. H., \& Walls, A. (2012). Enduring travel involvement, destination brand equity, and travelers' visit intentions: A structural model analysis. Journal of Destination Marketing and Management, 1(1-2), 2735. https://doi.org/10.1016/j.jdmm.2012.07.002

Goyette, I., Ricard, L., \& Bergeron, J. (2010). e-WOM Scale : Word-of-Mouth Measurement Scale for eServices Context *. 23, 5-23.

Jalilvand, M. R., \& Ali Heidari. (2015). Comparing face to face and electronic word-of-mouth in destination image formation: the case of Iran. Journal Information Technology \& People, 28(1), 2-33.

Kremer, F., Viot, C., Kremer, F., Viot, C., Kremer, F., \& Viot, C. (2018). How store brands build retailer brand image To cite this version: HAL Id : hHal01803720 How store brands build retailer brand image. 40(7), 528-543.

Lee, S. J., \& Bai, B. (2016). Influence of popular culture on special interest tourists' destination image. Tourism Management, 52, 161-169. https://doi.org/10.1016/j.tourman.2015.06.019

Lee, W. I., Cheng, S. Y., \& Shih, Y. T. (2017). Effects among product attributes, involvement, word-ofmouth, and purchase intention in online shopping. Asia Pacific Management Review, 22(4), $223-229$. https://doi.org/10.1016/j.apmrv.2017.07.007

Li, P., Yang, X., Yang, L. X., Xiong, Q., Wu, Y., \& Tang, Y. Y. (2018). The modeling and analysis of wordof-mouth marketing. Physica A: Statistical Mechanics and Its Applications, 493, 1-16. https://doi.org/10.1016/j.physa.2017.10.050

Majid, N. (2013). Analisis Pengaruh Electronic Word of Mouth terhadap Brand Image dan Dampaknya pada Minat Beli Smartphone Samsung di Kota Malang Oleh. Journal of Chemical Information and Modeling, 53(9), 1689-1699.

Melania, K., \& Ellyawati, J. (2018). The Role of Online Promotion and Its Effect on Destination Loyalty. Kinerja, 22(2), 126-141. https://ojs.uajy.ac.id/index.php/kinerja/issue/view/239

Nicoletta, R., \& Servidio, R. (2012). Tourists' opinions and their selection of tourism destination images: An affective and motivational evaluation. Tourism Management Perspectives, 4, 19-27. https://doi.org/10.1016/j.tmp.2012.04.004

Novita, P., \& Lubis, A. R. (2018). Pengaruh Kepribadian Terhadap Loyalitas Dengan Persepsi Kualitas Merek Dan Niat Beli Sebagai Variabel Mediasi (Studi Pada Retailer Showroom Mobil Toyota Di Banda Aceh). Jurnal Ilmiah Mahasiswa Ekonomi Manajemen, 3(2), 148-161.

Phillips, W. M. J., Asperin, A., \& Wolfe, K. (2013). Investigating the effect of country image and subjective knowledge on attitudes and behaviors: U.S. Upper Midwesterners' intentions to consume Korean Food and visit Korea. International Journal of Hospitality Management, 32(1), 49-58. https://doi.org/10.1016/j.ijhm.2012.04.003 
Putra, E. W., Kumadji, S., \& Yulianto, E. (2016). Pengaruh Diskon Terhadap Minat Beli Serta Dampaknya Pada Keputusan Pembelian. Jurnal Administrasi Bisnis (JAB), 38(2), 184-193.

Putri, U. A. I., \& Yasri. (2020). The Effect of Social Media, Word of Mouth on the Destination Image and Its Impact on the Visit Decision to Tourism Destinations in the City of Padang. 152, 686-695. https://doi.org/10.2991/aebmr.k.201126.076

Qadry, R. A., \& Yasri. (2019). The Impact of Product Attributes, Personality, and Word of Mouth on Purchase Intention Product of Gift of Typical Food of West Sumatera. 97(Piceeba), 440-446. https://doi.org/10.2991/piceeba-19.2019.50

Qu, H., Kim, L. H., \& Im, H. H. (2011). A model of destination branding: Integrating the branding and destination image concepts. Tourism Management, 32(3), 465-476. https://doi.org/10.1016/j.tourman.2010.03.014

Rittichainuwat, B., \& Rattanaphinanchai, S. (2015). Applying a mixed method of quantitative and qualitative design in explaining the travel motivation of film tourists in visiting a film-shooting destination. Tourism Management, 46, 136-147. https://doi.org/10.1016/j.tourman.2014.06.005

Semuel, H., \& Lianto, A. S. (2017). Pengaruh Strategi Promosi Stikom Interstudi terhadap Peningkatan Ekuitas Merek. InterKomunika, 2(2), 146. https://doi.org/10.33376/ik.v2i2.34

Setyaningsih, S., \& Murwatiningsih. (2017). Pengaruh Motivasi, Promosi Dan Citra Destinasi Pada Kepuasan Pengunjung Melalui Keputusan Pengunjung. Management Analysis Journal, 6(2), $123-133$. http://maj.unnes.ac.id

Sheehan, D., Hardesty, D. M., Ziegler, A. H., \& Chen, H. (Allan). (2019). Consumer reactions to price discounts across online shopping experiences. Journal of Retailing and Consumer Services, 51(February), 129-138. https://doi.org/10.1016/j.jretconser.2019.06.001

Toudert, D., \& Bringas-Rábago, N. L. (2016). Impact of the destination image on cruise repeater's experience and intention at the visited port of call. Ocean and Coastal Management, 130, 239-249. https://doi.org/10.1016/j.ocecoaman.2016.06.018

Whang, H., Yong, S., \& Ko, E. (2016). Pop culture, destination images, and visit intentions: Theory and research on travel motivations of Chinese and Russian tourists. Journal of Business Research, 69(2), 631641. https://doi.org/10.1016/j.jbusres.2015.06.020

Widyanto, R. G., \& Widayanto. (2019). Pengaruh Promosi Dan Word Of Mouth Terhadap Keputusan Berkunjung Melalui Destination Image (Studi Kasus pada Wisatawan Grand Maerakaca Semarang). 113.

Yasri, Y., \& Engriani, Y. (2018). An Analysis on Brand Image and Switching Intention of FliCompaniesiesr Customers with Word of Mouth (WOM) as The Intervening Variable. 57(Piceeba), 347-358. https://doi.org/10.2991/piceeba-18.2018.66

Yoon, Y. S., Lee, J. S., \& Lee, C. K. (2010). Measuring festival quality and value affecting visitors' satisfaction and loyalty using a structural approach. International Journal of Hospitality Management, 29(2), 335-342. https://doi.org/10.1016/j.ijhm.2009.10.002

Kotler, Philip. 2005. Manajemen Pemasaran. Jilid 1 dan 2. Jakarta : PT Indeks Kelompok Gramedia Kotler and Keller (2009). Marketing Management. Issue 13 Volume 1. Jakarta: Erlangga Publisher Kotler, Philip, A.B Susanto, Manajemen Pemasaran di Indonesia, Jakarta: Salemba Empat, 2001 